\title{
SECTIONS 459-461 COMPANIES ACT 1985 IN FLUX: THE FUTURE OF SHAREHOLDER PROTECTION
}

\author{
JeNNIFER PAYNE*
}

\section{INTRODUCTION}

SECTIONS 459-461 of the Companies Act 1985 are at the forefront of the remedies available to protect minority shareholders from oppression. ${ }^{1}$ The danger is that companies will be run exclusively in the interests of the controlling shareholders, and that the interests of the minority shareholders will be ignored, or at least not fully recognised. ${ }^{2}$ These sections provide general protection from oppression for minority shareholders. They are drafted in deliberately wide terms. Section 459(1) provides that:

[a] member of a company may apply to the court by petition for an order ... on the ground that the company's affairs are being or have been conducted in a manner which is unfairly prejudicial to the interests of its members generally or of some part of its members (including at least himself) or that any actual or proposed act or omission of the company (including an act or omission on its behalf) is or would be so prejudicial.

It has been left to the courts to define the scope of the protection afforded by these sections. A number of important recent decisions, in particular that of the Court of Appeal in Clark v. Cutland, ${ }^{3}$ have

* Fellow of Merton College, Oxford and Travers Smith lecturer in Corporate Finance Law. My thanks to Dan Prentice for his comments on an earlier draft. Any errors remain entirely my own.

${ }^{1}$ Oppression here is used to mean the transgression of a right or interest held by a minority shareholder: see D. Prentice, "The Theory of the Firm: Minority Shareholder Oppression: Sections 459-461 of the Companies Act 1985" (1988) 8 O.J.L.S. 55. It is not used in the narrow sense adopted to interpret this term as used in section 210 Companies Act 1948 (see note 6 and associated text below).

${ }^{2}$ This is a matter of concern to investors, but there are also public policy arguments in favour of ensuring that minority shareholders are adequately protected from the opportunistic behaviour of majority shareholders. If investors are inadequately protected there is a danger that investors will refuse to invest if they are offered only a minority stake or more likely that the cost of securing their investment will rise. This protection could take a number of forms. In public companies and in the larger private companies the market may help to regulate minority protection from oppression, especially if the company in question needs regular access to the capital markets for fresh injections of equity finance. In smaller companies, and in particular "quasi partnership companies, self help, in the form of a renegotiation of the contractual basis of their relationship with the company, is possible, although self help of this kind is unlikely to be available to the majority of minority shareholders.

3 [2003] EWCA Civ 810; [2004] 1 W.L.R. 783. 
provided substantial guidance as to the role and scope of section 459. This article will examine these new developments and their implications for the future of shareholder protection.

\section{The Scope of Section 459 Protection}

It has been suggested that two main questions arise for consideration in the context of section $459 .{ }^{4}$ First, should the section be seen as providing merely protection from harms which are unlawful independent of this section and, if not, how and where should the courts draw the line of "unfair prejudice"? Second, what is the relationship between section 459 and the derivative action? Two decades of energetic litigation, and in particular the decision of the House of Lords in O'Neill v. Phillips, ${ }^{5}$ have done much to answer the first of these questions.

It is clear that section 459 is intended to protect minority shareholders from more than just a breach of their legal rights. The adoption of the language of "unfair prejudice" within the current version of the statutory protection was a deliberate attempt to avoid the narrow rights-based protection that had existed previously: $^{6}$

[i]n section 459 Parliament has chosen fairness as the criterion by which the court must decide whether it has jurisdiction to grant relief. It is clear ... that it chose this concept to free the court from technical considerations of legal right and to confer a wide power to do what appeared just and equitable. ${ }^{7}$

Initially, the courts categorised this extension as a protection of the "legitimate expectations" of shareholders. ${ }^{8}$ However, the House of Lords in O'Neill v. Phillips moved away from this language and towards a more private law orientated approach. ${ }^{9}$

${ }^{4}$ Gower and Davies, Principles of Modern Company Law, 7th edn., by Paul Davies (London 2003), pp. 512-3.

${ }^{5}$ [1999] 1 W.L.R. 1092; see D. Prentice and J. Payne, "Section 459 of the Companies Act 1985The House of Lords' View" (1999) 115 L.Q.R. 587.

${ }^{6}$ When the statutory oppression remedy was first introduced in section 210 of the Companies Act 1948 the ambit of this section was both narrowly drafted and interpreted narrowly by the courts. In particular this section referred to the protection of the minority shareholders from "oppression" which was interpreted by the judges to mean behaviour which was "burdensome, harsh and wrongful" (Scottish Co-operative Wholesale Society Ltd. v. Meyer [1959] A.C. 324, 342 per Viscount Simonds (emphasis added)) so that only behaviour which was unlawful independently of this section could be protected. See Jenkins Committee, Report of the Company Law Committee, Cmnd. 1749 (HMSO, London 1962), para. 203.

${ }^{7}$ O'Neill v. Phillips [1999] 1 W.L.R. 1092, 1098 per Lord Hoffmann. This concept was accepted even before O'Neill, see e.g., Re Saul D. Harrison \& Sons plc [1995] 1 B.C.L.C. 14, 17-20 per Lord Hoffmann.

${ }^{8}$ Re Saul D. Harrison \& Sons ple [1995] 1 B.C.L.C. 14, 19 per Lord Hoffmann.

9 There is no doubt that their Lordships were aware that their judgment involved a narrowing of the previous ambit of unfair prejudice. Lord Hoffmann noted that the Law Commission had previously criticised a similar line on unfairness taken by Lord Wilberforce in Ebrahimi v. Westbourne Galleries Ltd. [1973] A.C. 360, 379 in the context of the "just and equitable" 
Lord Hoffmann stated that "unfairness may consist in a breach of the rules or in using the rules in a manner which equity would regard as contrary to good faith."10 Accordingly, a section 459 petition can be based on a strict infringement of legal rights, such as a breach of the articles, or on the unfair use of power which abuses the enjoyment of legal rights, such as the use of section 303 of the Companies Act 1985 to remove someone from their directorship in circumstances where they have only an oral agreement to remain a director. Situations in which a bargain has been reached by the parties but which is located in informal, nonlegally enforceable understandings between the shareholders rather than in the company's formal constitution can also found a section 459 petition. ${ }^{11}$ On the facts of $O$ 'Neill their Lordships held that no unfairness had arisen. The lack of a concluded agreement between the parties was an "insuperable obstacle" 12 to the petitioner.

The role of section 459 outside these contractual situations did not arise for discussion in $O^{\prime} N e i l l$, but Lord Hoffmann undoubtedly accepted that other forms of conduct can be regarded as unfair for the purposes of section $459 .{ }^{13}$ The current wording of the section, and in particular the words "of its members generally", make it clear that alleged wrongdoing which affects all of the members of a company can give rise to a petition under this section. ${ }^{14}$ It was clear prior to O'Neill that breaches of directors' duties to the company could found a section 459 petition. Examples include petitions based on diversions of the company's business to rival companies in which the majority are interested, ${ }^{15}$ the exercise of

ground of winding up under section 122(1)(g) of the Insolvency Act 1986. The Law Commission considered that this might limit the scope of the concept unduly and that "conduct which would appear to be deserving of a remedy may be left unremedied" (Law Com. No. 246, Shareholders' Remedies (1997), para. 4.11). Their Lordships' response in O'Neill v. Phillips was a pragmatic one. A balance has to be struck between the breadth of the discretion given to the court and the principle of legal certainty. Petitions under section 459 are often lengthy and expensive. It is highly desirable that lawyers should be able to advise their clients whether or not a petition is likely to succeed. Lord Hoffmann justified a narrower ambit for the concept of unfair prejudice on this basis, a point which was endorsed by the Company Law Review: Modern Company Law for a Competitive Economy, Completing the Structure, URN 00/1335 (November 2000), paras. 5.77-5.79 and the Final Report, URN 01/942 and 943 (June 2001), para. 7.41.

${ }_{10}$ [1999] 1 W.L.R. 1092, 1099 per Lord Hoffmann.

11 It has been suggested that these non-contractual understandings must be relied upon by the minority shareholder before they can found a section 459 petition: Re Guidezone [2000] 2 B.C.L.C. 321, 356 per Jonathan Parker J.

12 [1999] 1 W.L.R. 1092, 1103 per Lord Hoffmann.

13 Ibid., at p. 1101 .

${ }^{14}$ See Companies Act 1989, section 145, Sch. 19, para. 11, which added these words with effect from 4 February 1991.

${ }^{15}$ E.g., Re London School of Electronics Ltd. [1986] Ch. 211; Re Cumana Ltd. [1986] B.C.L.C. 430. 
directors' powers for an improper purpose ${ }^{16}$ and a failure of directors to act bona fide in the best interests of the company. ${ }^{17}$ This use of section 459 petitions undoubtedly survives the decision in $O^{\prime} N$ ill. ${ }^{18}$

With the first question regarding section 459 largely resolved, attention has turned to the second, namely the interaction of section 459 and derivative actions. This debate is an obvious consequence of the courts' acceptance of the use of section 459 in circumstances where directors have breached their duties to the company. Shareholder litigation in relation to wrongs done to the company has traditionally been via the derivative action. As regards section 459 , the courts drew a distinction between situations in which the shareholder used the breach of duty to the company to found a claim for personal relief, in which case the claim had the potential to succeed, and those in which the shareholder sought relief for the company, in which case the claim was not allowed:

The very same facts may well found either a derivative action or a section 459 petition. But that should not disguise the fact that the nature of the complaint and the appropriate relief is different in the two cases. Had the petitioners' true complaint been of the unlawfulness of the respondent's conduct, so that it would be met by an order for restitution, then a derivative action would have been appropriate and a section 459 petition would not. But that was not the true nature of the petitioners' complaint. They did not rely on the unlawfulness of the respondent's conduct to found their cause of action; and they would not have been content with an order that the respondent make restitution to the company. They relied on the respondent's unlawful conduct as evidence of the manner in which he had conducted the company's affairs for his own benefit and in disregard of their interests as minority shareholders; and they wanted to be bought out. They wanted relief from mismanagement, not a remedy for misconduct. ${ }^{19}$

A good example of this situation is Re Saul D. Harrison \& Sons plc. ${ }^{20}$ The petitioner brought a section 459 petition based on allegations that although the company had substantial net assets,

\footnotetext{
${ }^{16}$ Re A Company Ex p Glossop [1988] 1 W.L.R. 1068, although the section 459 petition in that case was unsuccessful, in part because before the Companies Act 1989, the wrong affected all of the members and not some part of the members (see n. 14 and associated text).

${ }^{17}$ Re Saul D. Harrison \& Sons plc [1995] 1 B.C.L.C. 14, although the allegation was not made out on the facts of that case.

${ }^{18}$ Clark v. Cutland [2003] EWCA Civ 810; [2004] 1 W.L.R. 783 is one such example. Other categories of unfair prejudice are also possible, see e.g., Re A Company [1986] B.C.L.C. 382 regarding the use of the provisions of the City Code on Takeovers to judge whether the directors had behaved in an unfairly prejudicial manner (cf. Re Astec (BSR) plc [1998] 2 B.C.L.C. 556).

19 Re Charnley Davies Ltd. (No. 2) [1990] B.C.L.C. 760, 784 per Millett J.

${ }^{20}$ [1995] 1 B.C.L.C. 14.
} 
the prospects for its business were so poor that any reasonable board would have closed down the company and distributed the assets to the shareholders, instead of which the directors allowed the assets to be dissipated in losses in order to preserve their own inflated salaries. Inter alia the petitioner relied on the directors' breach of duty to the company, in failing to take decisions bona fide in the interests of the company, to establish the section 459 petition. The remedy sought was, however, personal, namely the purchase of her shares. On the facts the Court of Appeal held that there was no basis for finding that the directors had abused their fiduciary powers, or had conducted the company's affairs in breach of its articles or of the Companies Act. However, it was accepted that if the directors had acted unlawfully, or breached the articles, or if the petitioner could show some other legitimate expectation that the directors would not act as they had, the potential for a successful section 459 petition did exist: "[e]nabling the court in an appropriate case to outflank the rule in Foss v. Harbottle was one of the purposes of [section 459]." ${ }^{21}$ Until recently, it was accepted that this "outflanking" could occur only in a limited sense. A section 459 petition could rely on a breach of duty to the company to found an action for personal relief, but could not give rise to corporate relief, beyond that stated in section 461(2)(c) Companies Act 1985 which allows for the possibility of the petitioning shareholder to bring a derivative action on the company's behalf. ${ }^{22}$ The House of Lords did not address this issue in $O^{\prime} N e i l l$, since that case involved only wrongs done to the petitioner personally.

The Court of Appeal in Clark v. Cutland ${ }^{23}$ has now accepted that substantive corporate relief can be obtained via a section 459 petition. Mr. Clark and Mr. Cutland were equal shareholders in a company and its sole directors. Mr. Cutland misappropriated more than $£ 500,000$ from the company without Mr. Clark’s knowledge and took from the company without authority other large payments by way of salary, pension contributions and other benefits. When these facts came to light Mr. Clark began a derivative action on behalf of the company. He then commenced a section 459 petition. The two actions were consolidated. The judge acknowledged that there was a wide jurisdiction under section 461 to grant the same relief as would have been granted in the derivative action and made an order under section 461 for $\mathrm{Mr}$. Cutland to repay to the company over $£ 1.1$ million. The Court of

${ }^{21}$ Ibid., at p. 18 per Hoffmann L.J.

${ }^{22}$ Although the Inner House of the Court of Session accepted that the position was different in Scotland in Anderson v. Hogg (2002) S.L.T. 354; [2002] B.C.C. 933 and see also Lowe v. Fahy [1996] 1 B.C.L.C. 262.

23 [2003] EWCA Civ 810; [2004] 1 W.L.R. 783. 
Appeal addressed a number of issues. However, in relation to the potential scope of section 459 only Arden L.J. commented, and she did so only briefly.

Arden L.J. held that Mr. Clark could obtain a substantive remedy for the company under section 461 , and that this remedy could include proprietary elements. In addition she stated that "although the relief sought is claimed under section 461, it is sought for the benefit of the company and ... it is, therefore, open to Mr. Clark to seek an order against the company for payment to him of any costs incurred by him on this appeal (and, possibly, with respect to the issue in the court below)." ${ }^{24}$ Although an indemnity of this kind is well accepted in relation to derivative actions, the court had never previously accepted this possibility in relation to section 459 petitions. $^{25}$

Following Clark v. Cutland it seems that minority shareholders can make use of section 459 to obtain a substantive remedy for the company in relation to a wrong done to the company, and can potentially obtain a costs order so that the company funds this claim. Arden L.J. gave no reasons for this expansion of the role of section 459. However, some strong arguments do exist to support this decision. When the Jenkins Committee considered this point it concluded that minority shareholders should have the right to bring a section 459 petition where a wrong is done to the company and the control vested in the majority is used wrongfully in order to prevent action being taken by the wrongdoer. In such circumstances the Jenkins Committee stated that the shareholders had been "indirectly wronged". ${ }^{26}$ On this view it is not the wrong to the company per se which founds the claim but instead the wrong done to the shareholder when the controllers misuse their control of the company to prevent an action being brought.

Millett J. makes a similar point in Re Charnley Davies Ltd. (No. 2). ${ }^{27}$ The same set of facts can give rise to a complaint both of a breach of duty owed to the company, which is prosecuted by the company or by a minority shareholder suing on behalf of the company (claim A), and to a complaint by the minority shareholder that the controllers of the company have disregarded the interests of the minority in attempting to prevent any action to regress the wrong done to the company (claim B). ${ }^{28}$ Millett $\mathrm{J}$.

24 Ibid., at para. [35].

25 But see D. Prentice, "The Theory of the Firm: Minority Shareholder Oppression: Sections 459-461 of the Companies Act 1985" (1988) 8 O.J.L.S. 55, 65 where Prof. Prentice suggests this possibility.

26 Report of the Company Law Committee, Cmnd. 1749 (1962), para. 206.

27 [1990] B.C.L.C. 760.

28 This seems to accord with the courts' analysis of derivative actions: see e.g., Nurcombe v. Nurcombe [1985] 1 W.L.R. 370, 378 per Browne-Wilkinson L.J. 
asserts that claim A can only be brought by the shareholder via a derivative action, ${ }^{29}$ subject to the standing requirements of Foss v. Harbottle, whereas the decision of the Court of Appeal in Clark v. Cutland allows a shareholder the possibility of bringing both claims via section 459. However, Millett J.'s view is not necessitated by the terms of section 459 and indeed this view looks odd when it is considered that section 459 already allows a corporate remedy to be awarded by the courts via section 461(2)(c), albeit that this remedy is procedural and not substantive in form. In circumstances where a wrong is done to the company and corporate relief is sought by a petitioner it is difficult to see why the cost and inconvenience of two sets of proceedings should be preferable to the court awarding corporate relief directly under section $461 .{ }^{30}$ Arguably, once the court has acknowledged a breach of duty by the directors to the company, offering substantive relief to the company in some circumstances ought to be within the wide discretion of the court under section 461. In fact, in light of recent developments in relation to the reflective loss principle, it might be argued that it is more appropriate to give a remedy to the company than to the shareholder at this point. ${ }^{31}$ However, there are important distinctions between the two forms of shareholder litigation which need to be borne in mind. In particular, the rules relating to derivative actions, such as the restrictive provisions on standing ${ }^{32}$ reflect the underlying principle of majority shareholder rule in companies. Section 459 is not based on the same theoretical underpinnings and therefore some care is needed if a section 459 petition is to be used as a substitute for a derivative action. These issues are explored in the next section.

The decision in Clark v. Cutland is not surprising or unwelcome. However, the decision has potentially important ramifications for the future development of shareholder litigation. In particular if section 459 can now be used to provide a substantial remedy to the company, the relationship between the derivative action and section 459 needs to be reassessed.

${ }^{29}$ Millett J. solved the difficult question of deciding which complaint a shareholder is making by inspecting the nature of the remedy sought. If personal a section 459 claim is acceptable, if corporate a derivative action.

30 The chances of a petitioning shareholder wishing to undertake a second piece of litigation are also extremely unlikely given the fact that in most circumstances they are seeking to exit the company by obtaining a buy out order. Unsurprisingly section 461(2)(c) Companies Act 1985 has been little used in practice.

${ }^{31}$ Discussed below at Section III.G.

32 See Section III.B below. 


\section{Comparing and Contrasting Shareholder Protection via Section 459 and the Derivative Action}

The law regarding the ability of a minority shareholder to bring a derivative action has been criticised as being 'complex and obscure'. ${ }^{33}$ The Law Commission has recognised the severe limitations which attach to the current derivative action regime, and has recommended its replacement by a new statutory derivative action, a view endorsed by the Company Law Review and now included in the Company Law Reform Bill. ${ }^{34}$ By contrast section 459 is a flexible remedy for shareholders which they are actually likely to use. ${ }^{35}$ Clark v. Cutland will undoubtedly make section 459 even more attractive for minority shareholders, as it expands the circumstances in which minority shareholders can make use of the statutory oppression remedy. Indeed Clark v. Cutland may lead to section 459 entirely superceding the derivative action. Many of the necessary elements for section 459 to be used by shareholders to bring a claim on behalf of the company are already in place. For example, recent caselaw has established the ability of shareholders in section 459 petitions to get access to the company's documents, ${ }^{36}$ to seek adequate disclosure ${ }^{37}$ and to obtain interim relief to protect the assets of the company pending determination of the petition. ${ }^{38}$ This section will investigate the respective merits of a derivative action and a section 459 claim for shareholders wishing to bring a claim on behalf of the company in the wake of Clark v. Cutland.

\section{A. Standing Requirements}

Standing requirements for section 459 petitions appear at least as generous, if not more so, than the standing requirements for derivative actions. The only claimants entitled to bring a derivative action on behalf of a company are the current members. ${ }^{39}$ No

33 Law Commission, Shareholders' Remedies (Law Com CP 142, 1996) para. 6.6.

34 See Modern Company Law for a Competitive Economy, Developing the Framework URN $00 /$ 656 (March 2000), Completing the Structure, URN 00/1335 (November 2000) and the Final Report, URN 01/942 and 943 (June 2001). The proposals for a statutory derivative action are included in the DTI's 'Draft clauses and explanatory material' (July 2002, available at www.dti.gov.uk/cld/facts/clr.htn) which supplements its March 2001 White Paper, Company Law Reform, Cm 6456. The provisions relating to derivative actions (Part O of the company Law Reform Bill) implement the suggested reforms of the Law Commission.

35 Many of the aspects of section 459 which make it a popular choice for minority shareholders, whether pursuing personal or corporate claims, are explored in Section III of this article.

36 CAS (Nominees) Ltd. v. Nottingham Forest FC Plc [2001] 1 All E.R. 954. Although this case concerned section 459 petitions, it is probable that the principle set out in the case applies generally to shareholder litigation and therefore could be applied in a derivative action.

37 Wyatt v. Frank Wyatt \& Son Ltd. [2003] EWHC 520 (Ch).

38 Re Premier Electronics (GB) Ltd. [2002] 2 B.C.L.C. 634; Reiner v. Gershinson [2004] EWHC 76 (Ch); [2004] 2 B.C.L.C. 376.

39 The Law Commission recommend no change to this position as in their view it accurately reflects the nature of a derivative action: Law Com. No. 246, Shareholders' Remedies (1997), para. 6.50. This contrasts with the more generous standing requirements adopted elsewhere. In 
percentage test is applied. ${ }^{40}$ No restrictions are made as to the type of company: minority shareholders in all companies, from the smallest private company to the largest public company ${ }^{41}$ have the potential to bring a derivative action claim. Since the claim in a derivative action is that of the company, a shareholder can bring a derivative claim in relation to wrongs which were done to a company before she became a member. ${ }^{42}$ This is the case even though the shareholder may gain a potential windfall thereby. ${ }^{43} \mathrm{By}$ the same token, however, the right to bring a claim is lost when a shareholder transfers his or her shares in the company.

As regards section 459 petitions, these may be brought by current members ${ }^{44}$ irrespective of the size of their minority shareholding or the nature of the company. ${ }^{45}$ However, section 459 extends to "a person who is not a member of a company but to whom shares in the company have been transferred or transmitted by operation of law" ${ }^{46}$ such as a member's trustee in bankruptcy or personal representative. A recent case has suggested a further level of flexibility regarding who can bring a section 459 petition. In Atlasview Ltd. v. Brightview $L t d .^{47}$ the petition was brought by individuals who held only the beneficial interest in shares in the company. The beneficiaries argued that they had suffered unfair prejudice. However, beneficial owners of shares do not fall within the definition of a member of the company. ${ }^{48}$ The nominee holding the shares on their behalf was the proper person to bring the

Singapore, for example, a complainant for the purposes of a derivative action is defined as including any person "who, in the discretion of the Court, is a proper person to make an application": Singapore Companies Act 1994, section 216A(1)(c). Canada has adopted a similar catch-all "proper person" category: Canadian Business Corporations Act, section 238. In Australia, the category is wider than that in the UK, though narrower than Singapore and Canada, comprising members, former members, those entitled to be registered as members of the company or a related company, as well as officers or former officers of the company: Corporations Act 2001, section 236.

${ }^{40}$ Cf. e.g., German Stock Corporation Act 1965, Art. 147 as amended.

${ }^{41}$ However the size of the company may make a difference to the ease with which minority shareholders may succeed in litigation. See A.J. Boyle, Minority Shareholders' Remedies (Cambridge 2002), esp. pp. 12-13 regarding the position of shareholders in listed companies.

42 Seaton v. Grant (1867) LR 2 Ch. App. 459.

43 Regal (Hastings) Ltd. v. Gulliver [1967] 2 A.C. 134n, 157 per Lord Porter.

${ }^{44}$ Section 459 petitions are generally available only to minority shareholders: Re Legal Costs Negotiators Ltd. [1999] 2 B.C.L.C. 171. In Singapore, any member or holder of a debenture may petition and in some circumstances the Minister may also apply to the court under the equivalent of section 459: Singapore Companies Act 1994, section 216. In Canada the same definition of "complainant" is adopted for the purposes of the statutory oppression remedy as is adopted for the purposes of the derivative action: Canadian Business Corporations Act, sections 241 and 238 and see [note 38] above. For Australia, see Corporations Act 2001, section 234.

45 The position regarding public companies is dealt with in detail at Section III.H below.

${ }^{46}$ Companies Act 1985, section 459(2).

${ }^{47}$ [2004] EWHC 1056 (Ch); [2004] 2 B.C.L.C. 191. Cf. Re Quickdome Ltd. [1988] B.C.L.C. 370. In another recent case, Arrow Nominees Inc. v. Blackledge [2000] 2 B.C.L.C. 167, the Court of Appeal allowed a nominee the right to bring a section 459 petition to protect the interests of beneficial shareholders, seemingly without discussion of these points.

${ }^{48}$ Companies Act 1985, section 22. 
section 459 petition, but that nominee could not demonstrate any loss, since it was a bare nominee with no economic interest in the value of the shares registered in its name. The judge adopted a flexible approach. While the beneficial shareholders could not bring the petition, when the nominee petitioned on their behalf the interests that the nominee could protect went "beyond the economic interest of the legal owner in the shares registered in his name". ${ }^{49}$ Therefore, while the beneficial shareholders had no direct right to petition, their indirect right was confirmed. No such flexibility exists in relation to derivative actions.

Under section 459 the personal nature of the claim prior to Clark v. Cutland, even when based on wrongs done to the company, meant that a shareholder was generally unable to obtain personal relief where the conduct upon which the petition was based took place before the shareholder obtained shares in the company. The only exception to this was, possibly, where the past conduct was of a continuing nature and continued to cause loss to the shareholder after that individual had acquired shares. However, presumably, following Clark v. Cutland, it is open to a shareholder to bring a section 459 petition in order to obtain corporate relief in relation to conduct which took place before they were a shareholder, and even to obtain an indemnity order for the costs of bringing such a petition. It is the company's claim which is being pursued in such circumstances. The gist of the shareholder's claim is that the directors/controllers are preventing a claim being brought in the company's own name. The court's primary concern is to prevent controllers behaving in this way and therefore any windfall for the petitioning shareholder, although recognised by the court, is "in fact as it is in law an immaterial consideration". 50 Nevertheless the existence of such a windfall is likely to be of interest to the shareholder in question.

\section{B. Leave Requirements}

Leave requirements are currently much stricter for minority shareholders bringing derivative actions compared to those bringing section 459 petitions, with good reason. Minority shareholders must establish their standing to bring a derivative action as a preliminary issue. ${ }^{51}$ This leave stage forms an important protection for the company. Under a derivative action the claim against the wrongdoers belongs to the company and should be treated as being

49 [2004] EWHC 1056 (Ch); [2004] 2 B.C.L.C. 191, para. [36] per Jonathan Crow, sitting as deputy judge of the High Court.

50 Regal (Hastings) Ltd. v. Gulliver [1967] 2 A.C. 134n, 157 per Lord Porter.

${ }^{51}$ Prudential Assurance Co. Ltd. v. Newman Industries Ltd. (No. 2) [1982] Ch. 204; Civil Procedure Rules 1998, Sch. 1, Part 19. 
equivalent to a claim by the company itself. Derivative actions have been viewed by the courts as an equitable exception to the proper plaintiff rule. 52 A derivative action is "nothing more than a procedural device for enabling the court to do justice to a company ... whoever comes forward to start the proceedings must be doing so for the benefit of the company and not for some other purpose". ${ }^{53}$ The right to bring a derivative action has been described as being afforded to an individual "as a matter of grace". ${ }^{54}$ A shareholder does not have an indefeasible right to bring an action on the company's behalf. ${ }^{55}$ The issue for the court is doing justice to the company ${ }^{56}$ and not to the petitioning shareholder. As a result the issue of ratification has particular relevance to the courts in determining whether or not to allow a derivative action to proceed: "where the alleged wrong [done to the company] is a transaction which might be made binding on the company ... by a simple majority of the members, no individual member of the company is allowed to maintain an action in respect of that matter". 57

Internal irregularities will be of no concern to the courts where they can be ratified by the shareholders in general meeting. ${ }^{58}$ Where a wrong is ratifiable then no derivative action will be allowed, ${ }^{59}$ although determining when an issue will be regarded by the courts as ratifiable will not always be simple. ${ }^{60}$ It has also been suggested that the views of an independent group within the company should be taken into account in determining whether or not to allow a derivative action to proceed. ${ }^{61}$ These two concepts, ratification and the views of an independent group within the company, are important in a collective process where the court is trying to weigh the protection of the minority, from abuse by the majority, against the protection of the company, from unnecessary litigation. If a

${ }_{52}$ Prudential Assurance Co. Ltd. v. Newman Industries Ltd. (No. 2) [1982] Ch. 204.

53 Nurcombe v. Nurcombe [1985] 1 W.L.R. 370, 376 per Lawton L.J.

${ }_{54}$ Gower, Modern Company Law, 4th ed. (London 1979), p. 652.

${ }^{55}$ See J. Payne 'Clean Hands in Derivative Actions' [2002] C.L.J. 76.

56 I.e., the shareholders as a whole in a solvent company.

${ }_{58}^{57}$ Edwards v. Halliwell [1950] 2 All E.R. 1064, 1066 per Jenkins L.J.

58 Foss v. Harbottle (1843) 2 Hare 461.

59 K. Wedderburn, "Shareholders' Rights and the rule in Foss v. Harbottle" [1957] C.L.J. 194.

${ }^{60}$ Law Com. No. 246, Shareholders' Remedies (1997); Modern Company Law for a Competitive Economy, Developing the Framework, URN 00/656 (March 2000), Completing the Structure, URN 00/1335 (November 2000) and the Final Report, URN 01/942 and 943 (June 2001), para. 7.46. For comment see J.Payne, "A Re-Examination of Ratification" [1999] C.L.J. 604; A.J. Boyle, Minority Shareholders' Remedies (Cambridge, 2002).

${ }^{61}$ Smith v. Croft (No. 2) [1988] Ch. 144. In that case Knox J. allowed the majority of the minority shareholders to determine whether to allow the litigation to proceed. Both the Law Commission and the Company Law Review have suggested that the views of an independent group within the company should continue to be a relevant factor for the courts: Law Com. No. 246, Shareholders' Remedies (1997), paras. 6.88-6.90; Modern Company Law for a Competitive Economy, Completing the Structure, URN 00/1335 (November 2000), para. 5.82 et seq. and the Final Report, URN 01/942 and 943 (June 2001), para. 7.46 et seq. 
shareholder has a unique interest in bringing the petition which is not shared by the other shareholders and if an independent group within the company is opposed to the action then it is proper that the derivative action should be denied. ${ }^{62}$ The current derivative action jurisdiction is undoubtedly complex and obscure. However, some of the hurdles facing minority shareholders and which make the derivative action cumbersome are there to protect the company against the single irritated shareholder who through malice or misjudgment would waste the company's time and money if allowed to litigate on the company's behalf. A good example is Barrett v. Duckett. $^{63}$ A derivative action was brought by a shareholder against a director for diverting company money into bank accounts held by him for himself and his wife jointly. However, this action was complicated by the fact that the claimant's daughter was engaged in a bitter matrimonial dispute with the defendant. The court refused to allow the derivative action since this claim was not being pursued "bona fide on behalf of the company". ${ }^{64}$

There is no leave stage in section 459 petitions. The Law Commission did consider adding an ex ante procedural hurdle to the section 459 petition, but did not recommend this additional hurdle be added to a process which is already very long and costly. ${ }^{65}$ This makes perfect sense if section 459 is only a personal form of action, but less sense if section 459 is to be developed as a vehicle for providing corporate relief. The closest equivalent to the leave requirement is the possibility of a strike out application by the respondent. ${ }^{66}$ The strike out application obviously operates in a different way to the leave requirement under the derivative action procedure. Perhaps most importantly, the application for leave must be brought by the shareholder in a derivative action, so that the court will always have the opportunity to consider the merits of the case ex ante, whereas this will only occur in section 459 proceedings if the respondent brings a strike out application. ${ }^{67}$ The judge will grant the motion to strike out if the motion is unarguable. ${ }^{68}$ The Court of Appeal has held that a petition should be struck out where the petitioner's conduct amounts to an abuse of the process

\footnotetext{
${ }^{62}$ Smith v. Croft (No. 2) [1988] Ch. 144.

${ }^{63}$ [1995] 1 B.C.L.C. 243.

64 Ibid., at 256 per Peter Gibson L.J.

${ }_{65}$ Law Com. No. 246, Shareholders' Remedies (1997).

${ }^{66}$ Civil Procedure Rules 1998, Part 3, r. 3.4.

${ }^{67}$ However, strike out applications do seem to be extremely common. For recent examples see e.g., Atlasview Ltd. v. Brightview Ltd. [2004] EWHC 1056 (Ch); [2004] 2 B.C.L.C. 191; Branch v. Bagley [2004] EWHC 426; Wyatt v. Frank Wyatt \& Son Ltd. [2003] EWHC 520 (Ch).

${ }^{68}$ See, e.g., Re Legal Costs Negotiators Ltd. [1999] 2 B.C.L.C. 171 for an example of a successful strike out; cf. Re Baltic Real Estate Ltd. (No. 1) [1993] B.C.L.C. 498.
} 
of the court. Fraudulent conduct, including the destruction of documents and the production of forged documents in the discovery process meant that it was in the interests of justice to terminate proceedings. ${ }^{69}$ It is possible that the courts will use this jurisdiction in order to strike out a petition on facts akin to those of Barrett v. Duckett, if the respondent makes an application for strike out. ${ }^{70}$ However, this protection still falls short of that currently offered by the leave stage of the derivative action. First, because it depends upon the respondent bringing the strike out application. Second because it remains unclear at present whether the courts will strike out Barrett v. Duckett and similar cases rather than leave them to be determined at full trial. Third, because it does not answer the other situations in which a derivative action would be barred at the leave stage, such as where the wrongdoing has been ratified by an ordinary resolution of the shareholders or where an independent organ within the company does not wish the action to proceed. ${ }^{71}$

Clark v. Cutland allows section 459 to be used by a minority shareholder to obtain a corporate remedy in response to a corporate wrong without going through the leave requirements which are in place in a derivative action and which are intended to protect the company. This potentially means that the decision whether to litigate on behalf of the company can be delegated to individual minority shareholders. ${ }^{72}$ Arden L.J. suggests no limits to this principle in Clark v. Cutland. However, it is inappropriate to allow a shareholder such as that in Barrettt v. Duckett to circumvent the procedural hurdles designed to protect the company by bringing a section 459 claim to litigate the same wrong.

If the courts wish to develop principles to deal with these issues then there are a number of options. To leave these issues to be dealt with at trial is unlikely to be satisfactory. At that point there are few tools available to judges to screen out inappropriate actions under section 459. Of course the courts have utilised the requirement of unfair prejudice as a general guide in determining when to exercise its powers under section 461. However, this concept has been developed in a way which focuses on the petitioner's position and whether his or her rights attaching to shares have been infringed. Lord Hoffmann's judgment in O'Neill

69 Arrow Nominees Inc. v. Blackledge [2000] 2 B.C.L.C. 167.

${ }^{70}$ The recent case of Branch v. Bagley [2004] EWHC 426 does lend some support to this view.

${ }^{71}$ Smith v. Croft (No 2) [1988] Ch. 114.

72 See J. G. MacIntosh, 'The Oppression Remedy: Personal or Derivative' (1991) 70 Can Bar Rev 29; L. Griggs \& J. Lowry, 'Minority Shareholder Remedies: A Comparative View' (1994) J.B.L. 463. 
v. Phillips $^{73}$ stresses the fundamentally promissory nature of the basis on which relief may be granted. This is understandable given the courts' view, before Clark v. Cutland, of section 459 as a personal claim to provide personal relief to the petitioner. However, this focus on inter-shareholder disputes provides no basis for determining whether or not a claim on the company's behalf under section 459 would be in the collective best interests of the shareholders. ${ }^{74}$ Of course it is possible that the concept of unfair prejudice could be developed in a way which takes account of these issues. ${ }^{75}$ Alternatively, the judges' discretion under section 461 could be used to refuse a substantive corporate remedy if the shareholder's claim was felt to compromise the collective position. ${ }^{76}$ However by that stage the time and expense of litigation has already been expended. An earlier intervention than this is required.

Every section 459 petition is currently allocated to the multitrack procedure under the new Civil Procedure Rules. ${ }^{77}$ There will always be a pre-trial review. ${ }^{78}$ This is the proper time for the court to determine whether the claim on the company's behalf under section 459 is in the collective best interests of the shareholders and should be allowed to proceed. This use of the pre-trial review is, understandably, not included within the Civil Procedure Rules at the present time. Ideally, this will change. A similar test is needed at this point to that currently undertaken by the courts when determining whether to allow a derivative action to proceed, where section 459 is being used to pursue a corporate claim. The assessment by the court should concentrate on whether the claim should be allowed to proceed in order to do justice to the company. ${ }^{79}$ The concept of ratification and the views of an

73 [1999] 1 W.L.R. 1092.

${ }^{74}$ One effect of the requirement of unfair prejudice may be to prevent some forms of corporate wrongdoing being litigated in some circumstances, for example where there is a breach by a director of his duty of care and skill and no gross mismanagement is involved. However, this operates in a manner unrelated to the issue of potential misuse of the jurisdiction by the petitioning shareholder.

75 Section 459 already contains reference to conduct which is unfairly prejudicial to the interests of the 'members generally' and there is no reason why unfair prejudice should not be expanded to take account of a much broader range of issues. The courts have been open to a broader interpretation of unfair prejudice in the past: Re A Company (No. 008695 of 1985) (1986) 2 B.C.C. 99 and see A.J. Boyle, Minority Shareholders' Remedies (Cambridge, 2002), Ch. 4. This would necessarily involve a consideration of some issues, such as whether the wrong had already been ratified, which had no place in section 459 in the past because of the personal nature of the remedy.

76 Presumably the petitioner could also be judged to have lost the right to a costs indemnity order since the Court of Appeal in Wallersteiner v. Moir (No. 2)[1975] Q.B. 373 determined that the right to such an order depends on whether or not the minority shareholder acted in good faith and reasonably in bringing proceedings.

77 Civil Procedure Rules Part 49; Practice Direction 49B.10; Civil Procedure Rules, Part 29.

${ }^{78}$ Civil Procedure Rules, r. 29.2 (1)(b)(ii).

79 The Law Commission looked at introducing a modified leave stage in its suggested statutory derivative action. This effects some improvements on the existing regime but is still open to criticism, see e.g., A.J. Boyle, Minority Shareholders' Remedies (Cambridge 2002), Ch. 3. 
independent organ within the company have, unsurprisingly, had no place in section 459 petitions to date. They have no place in claims for personal relief. However, once section 459 performs a collective function it is difficult to see why concepts such as ratification and the views of an independent organ should not be relevant to the court in determining whether a section 459 petition which seeks substantive corporate relief should succeed. Of course, finding the right balance between appropriate and inappropriate claims will not be easy. It is something with which the derivative action jurisdiction has been struggling for more than 150 years. There is no magic formula to be adopted and indeed the recommended reforms put forward by the Law Commission and included in the Company Law Reform Bill seem unlikely to effect much positive change. ${ }^{80}$ However, a helpful start would be an acceptance that the courts need to address these issues at the pre-trial review stage of a section 459 petition where a corporate claim is being pursued. Undoubtedly the courts will have to revisit the boundaries between appropriate and inappropriate actions at that point. It is hoped that this will provide an impetus for judicial reform of this issue.

\section{Corporate Groups}

The attitude of the courts to corporate groups appears to be more flexible in section 459 petitions than in derivative action proceedings. One question which has arisen in relation to derivative actions is whether a "double derivative" or "multiple derivative" action should be possible. ${ }^{81}$ Broadly these involve a shareholder in a parent company being able to bring a derivative action on behalf of a subsidiary or associated company within a group. Consider a situation in which a shareholder in one company, $X$, can show that the directors of company $\mathrm{X}$ and of subsidiary $\mathrm{Y}$ have wrongly prevented the enforcement of a cause of action vested in Y. Should that shareholder be able to bring a derivative action to prevent this abuse? Such actions are available in other jurisdictions. ${ }^{82}$ They are not currently recognised in the UK and the Law Commission did not recommend their introduction. ${ }^{83}$ This is unfortunate. Multiple derivative actions are justifiable where the directors are turning a

${ }^{80}$ Boyle, Minority Shareholders' Remedies, Ch. 3.

81 The Law Commission preferred the term "multiple derivative action": Law Com Consultation Paper No. 142, Shareholders Remedies (1997), para. 16.51.

82 E.g., the US (see e.g., Kaufman v. Wolfson, 151 NYS 2d. 530 (1950) for an early example) and New Zealand (New Zealand Companies Act 1993, section 165 (1)). The "proper person", category in Singapore Companies Act, section 216 is wide enough to allow for this possibility, as is the equivalent category in the Canadian Business Corporations Act (s. 238) (see note [38] and associated text).

83 Law Com. No. 246, Shareholders' Remedies (1997), para. 6.110. Cf. DTI, Modern Company Law for a Competitive Economy: Developing the Framework (March 2000), para. 4.133. 
collective blind eye to the abuse of managers or directors at a lower level in a group hierarchy.

The courts in section 459 litigation have shown a more flexible approach to corporate groups. Where a parent company has assumed detailed control over the affairs of its subsidiary and treats the financial affairs of the two companies as those of a single enterprise, actions taken by the parent in its own interest may be regarded as acts done in the conduct of the affairs of the subsidiary, even where the companies are not engaged in the same type of business. ${ }^{84}$ This is the case even though the courts continue to regard the separate companies in this situation as separate legal entities for other purposes. ${ }^{85} \mathrm{~A}$ recent example is Gross v. Rackind. ${ }^{86}$ In this case all the allegations of unfair prejudice relied upon by the shareholders in a holding company to support their section 459 petition related to the conduct of the business of that company's wholly owned subsidiaries. ${ }^{87}$ In refusing to strike out the petition the Court of Appeal emphasised that the conduct of the affairs of one company can constitute conduct of the affairs of another for section 459 purposes. The interests of the shareholders in the parent company could be affected by conduct occurring in relation to a subsidiary: "the section warrants the court in looking at the business realities of a situation, and does not confine them to a narrow, legalistic view". ${ }^{88}$ As a result a minority shareholder within either a parent or subsidiary can argue that the interests of one company can be the interests of the other. Presumably also shareholders in one subsidiary could claim that their interests were affected by conduct taking place in another subsidiary company in appropriate circumstances. Following Clark v. Cutland it seems that a shareholder could potentially make use of section 459 in order to effectively achieve a multiple derivative action.

\section{Breadth of Protection}

The scope of protection offered to shareholders under section 459 is obviously wider than that on offer under the derivative action. The derivative action operates in situations where the company is the proper claimant, and so does not cover situations in which wrongs

${ }^{84}$ Scottish Co-operative Wholesale v. Meyer Society Ltd. [1959] A.C. 324, 343 per Viscount Simonds (expressly adopting the earlier words of Lord President Cooper) and cited with approval in Nicholas v. Soundcraft Electronics Ltd. [1993] B.C.L.C. 360.

85 Adams v. Cape Industries plc [1990] Ch. 433.

${ }_{87}^{86}$ [2004] EWCA Civ 815; [2004] 4 All E.R. 735.

87 This is the converse of the situation in Nicholas v. Soundcraft Electronics Ltd. [1993] B.C.L.C. 360 in which the holding company was conducting the business of the subsidiary.

${ }^{88}$ Nicholas v. Soundcraft Electronics Ltd. [1993] B.C.L.C. 360, 368 per Ralph Gibson L.J. 
are suffered by the shareholders personally. ${ }^{89}$ However, even in relation to wrongs done to the company, the protection offered by section 459 is broader. The derivative action creates no substantive standard of liability, but rather draws upon the law of fiduciary duties, allowing some but not all breaches of duty by a director to found a derivative action. The current state of the law regarding the wrongs which may be litigated under the fraud on the minority exception to Foss v. Harbottle is confused but would seem to cover only some forms of misappropriation of corporate property ${ }^{90}$ and gross negligence in which the directors have benefited themselves at the expense of the company. ${ }^{91}$ Simple negligence, where no such benefiting occurs, does not fall within the present remit of a derivative action because such a breach of duty by the directors is regarded as ratifiable. ${ }^{92}$ The recommended reforms of the derivative action put forward by the Law Commission would change this so that all breaches of directors' duties, including mere negligence, could potentially be litigated by way of a derivative action. ${ }^{93}$

By contrast section 459 creates liability where there has been conduct which is "unfairly prejudicial to the interests of the members generally". The courts have drawn upon the jurisprudence relating to fiduciary duties in interpreting the scope of section 459 but it is clear that the oppression remedy creates a standard which differs from both the common law of fiduciary duties and the list of fiduciary duties breach of which will found a derivative action, being narrower than the former and wider than the latter. For example, the courts have accepted that in certain circumstances negligence may give rise to an unfair prejudice petition. In $R e$ Elgindata $^{94}$ Warner $\mathrm{J}$. stated that the court would ordinarily be very reluctant to treat managerial decisions as contributing unfairly prejudicial conduct. Nevertheless he indicated that it would be open to the court in an appropriate case to find that serious mismanagement of the company could constitute unfair prejudice. What the court seems to require is serious and persistent mismanagement. ${ }^{95}$ The example given by Warner J. in Re Elgindata

\footnotetext{
${ }^{89}$ The exception of course is situations in which wrongs may have been done to shareholders, and they may have suffered loss, but the principle of reflective loss requires that the remedy be given to the company rather than to the shareholder. See Johnson v. Gore Wood \& Co. [2000] UKHL 65; [2002] A.C. 1 and Section III.G below.

90 See e.g., Cook v. Deeks [1916] 1 A.C. 554 cf. Regal (Hastings) Ltd. v. Gulliver [1967] 2 A.C. $134 \mathrm{n}$.

${ }_{91}$ Daniels v. Daniels [1978] Ch. 406.

92 Pavlides v. Jensen [1956] Ch. 565.

93 See Law Com. No. 246, Shareholders' Remedies (1997), paras. 6.23-6.57, esp. 6.38-6.41; these proposals were endorsed by The Company Law Review: Modern Company Law for a Competitive Economy, Completing the Structure, URN 00/1335 (November 2000), para. 5.82 et seq and the Final Report, URN 01/942 and 943 (June 2001), para. 7.46 et seq.

94 [1991] B.C.L.C. 959.

${ }_{95}$ See e.g, Re Macro (Ipswich) Ltd. [1994] 2 B.C.L.C. 354
} 
was "where the majority shareholders, for reasons of their own, persisted in retaining in charge of the management of the company's business a member of their family who was demonstrably incompetent". ${ }^{96}$ This is a higher standard than would be required to establish a breach of the common law duty of care owed by directors to their company but is nevertheless demonstrably more generous then the standard required before negligence can found a derivative action at the present time. ${ }^{97}$ This is another reason why minority shareholders are likely to prefer a section 459 petition to a derivative action. The intended reform of the derivative action would reverse this, ${ }^{98}$ although presumably the courts in section 459 petitions could then adopt the mere negligence standard too in order to stay in line with derivative actions. However, these reforms do not seem likely to emerge in the near future.

\section{E. Costs}

The position in relation to indemnity costs orders remains slightly more favourable to shareholders in derivative actions than in section 459 petitions, despite Arden L.J.'s judgment in Clark v. Cutland. In Wallersteiner v. Moir (No. 2), ${ }^{99}$ the Court of Appeal recognised the right of a minority shareholder to obtain an indemnity order in relation to the cost of financing a derivative action. This is determined as a preliminary issue at the same time as the application for locus standi is assessed. ${ }^{100}$ Fundamentally the right to a costs indemnity order will depend upon whether the minority shareholder acted in good faith and reasonably in bringing proceedings. By contrast no such order is generally available at common law where the shareholder's claim is not a derivative one. ${ }^{101}$ At the end of section 459 proceedings an order may be made on a "common fund" basis if the result of the case is beneficial to the members generally. ${ }^{102}$ In Clark v. Cutland Arden L.J. stated that where the claim is brought on the company's behalf "it is ... open to Mr. Clark to seek an order against the company for payment to him of any costs incurred by him on this appeal

\footnotetext{
96 [1991] B.C.L.C. 959, 994.

97 The scope of the statutory derivative action is broader than the current scope of section 459 protection in this regard: see Company Law Reform Bill, Part O.

98 See the Company Law Reform Bill, Part O (available at www.dti.gov.uk/cld/pdfs/ derivativeclaimsclauses.pdf).

99 [1975] Q.B. 373.

100 Civil Procedure (Amendment) Rules 2000, S.I. 2000/221. No changes to the current system are recommended by the Law Commission: Law Com. No. 246, Shareholders' Remedies (1997), para. 6.104.

101 Marx v. Estates and General Ltd. [1976] 1 W.L.R. 380.

102 Ibid.
} 
(and, possibly, with respect to the issue in the court below)."103 However, unlike the Wallersteiner v. Moir order which is made prior to the hearing of the main trial, in section 459 proceedings the order will only be made after the event if the court determines at that stage that the claim was indeed beneficial to the company. This involves more risk for the shareholder bringing the petition since the costs will have been incurred before the determination of whether an indemnity for those costs will be obtained. Hopefully this will involve more protection for the company as it should act as a disincentive to shareholders who seek to bring spurious claims.

One other distinction is worth highlighting as regards the funding of these two forms of shareholder litigation. It seems that conditional fee agreements ${ }^{104}$ cannot be employed in relation to the derivative action. These agreements can now be used generally in civil proceedings which seek to recover a monetary judgment, although the claimant has to obtain insurance to cover the defendant's legal costs in the event of losing. The claimant's legal expenses are met by the claimant's legal advisers who, in the event of winning the case, are reimbursed from an agreed proportion of the funds recovered by the successful judgment. ${ }^{105}$ However, in a derivative action it is a general rule that the proceeds of the action must accrue to the company alone, and this does not fit the conditional fee model where there is an expected diversion of funds to the claimant's legal adviser. ${ }^{106}$ In relation to section 459 actions, conditional fee agreements are possible where a monetary judgment is sought, such as the payment of previously unpaid dividends, as long as the petitioner obtains the requisite insurance "cover". A recent case has also accepted that awards of equitable compensation may be made under section 461, although these will be rare. ${ }^{107}$ It is interesting to speculate on what view the courts will take of a conditional fee agreement in relation to section 459 where the remedy sought is a monetary payment to the company, in order to compensate the company for a wrong done to it. It could be argued that if section 459 is effectively fulfilling the same function as the derivative action for these purposes, that by analogy no conditional fee arrangement should be possible. However the current cautious approach of the courts in relation to the funding

103 [2003] EWCA Civ 810; [2004] 1 W.L.R. 783, para. [35].

104 These are regulated under the Courts and Legal Services Act 1990 by provisions brought into force by subsequent statutory instruments: Conditional Fee Agreements Order 1998, S.I. 1998/1860; Civil Procedure Rules 1998, rule 48.9.

${ }^{105}$ See generally, K. Underwood, No Win, No Fee (Sutton Coldfield 1998).

${ }^{106}$ The Law Commission did not address this issue in their report: Law Com. No. 246, Shareholders' Remedies (1997).

107 Atlasview Ltd. v. Brightview Ltd. [2004] EWHC 1056 (Ch.); [2004] 2 B.C.L.C. 191. 
of derivative actions has been criticised, ${ }^{108}$ and it is to be hoped that the courts will be prepared to adopt a more flexible approach to conditional fee agreements where section 459 is used to obtain a remedy for the company.

\section{F. Clean Hands}

A lack of clean hands on the part of a minority shareholder has been held to be relevant when determining whether or not to allow the derivative action to proceed. ${ }^{109}$ It is suggested that since the claim in a derivative action belongs to the company equitable defences which exist between the shareholder personally and the wrongdoer should not in general be relevant to the derivative action. ${ }^{110}$

By contrast the general proposition in relation to section 459 petitions is that the clean hands defence does not apply. ${ }^{111}$ However, the petitioner's conduct may render the conduct complained of, even if prejudicial, not unfair, and the lack of clean hands on the petitioner's part may affect the relief granted even where unfair prejudice is established. ${ }^{112}$ In Re Jayflex Construction Ltd. ${ }^{113} \mathrm{R}$ and $\mathrm{M}$ ran five companies on a quasi-partnership basis, each effectively holding 50 per cent. of the shares in each company. Both $\mathrm{R}$ and $\mathrm{M}$ adopted the improper practice of having suppliers of goods and services invoice their main company for goods and services actually supplied to them personally. When the relationship broke down, $\mathrm{M}$ brought a section 459 petition, and $\mathrm{R}$ crosspetitioned on the basis that the relationship of trust and confidence had broken down between them. The judge held that no unfair prejudice had occurred. The improper conduct of both men meant that neither could complain about the improper behaviour of the other. Both the petition and the cross-petition were dismissed and no costs were awarded. It seems correct in principle that where the petitioners are seeking personal relief, as in Re Jayflex, the behaviour of the petitioning shareholder should be a relevant consideration for the court in determining whether unfair prejudice has occurred. Despite the statements made in Re London School of Electronics Ltd., cases like Re Jayflex suggest that in practice clean hands defence can exist in section 459 petitions. However, where

\footnotetext{
${ }^{108}$ E.g., Boyle, Minority Shareholders' Remedies, pp. 36-37, 82-84.

109 Towers v. African Tug Co. [1904] 1 Ch. 558; Nurcombe v. Nurcombe [1985] 1 W.L.R. 370.

${ }^{110}$ This issue is discussed in detail in J. Payne, "Clean Hands in Derivative Actions" [2002] C.L.J. 76.

111 Re London School of Electronics Ltd. [1986] Ch. 211, 222 per Nourse J. This is the case even though the clean hands defence does apply to a just and equitable winding up under section 122(1) $(\mathrm{g})$ of the Insolvency Act 1986.

112 Ibid., at p. 222.

113 [2003] EWHC 2008 (Ch.); [2004] 2 B.C.L.C. 145.
} 
the petitioning shareholder brings an action on behalf of the company then the same principles regarding clean hands should apply here as apply in relation to a derivative action claim.

\section{G. Reflective Loss}

In derivative actions the courts have had to deal with the issue of reflective loss for some time, but this principle has not been applied in section 459 cases. $^{114}$ With the decision in Clark v. Cutland allowing section 459 to be used as an alternative to derivative actions this situation needs to be reassessed. Where the defendant owes a duty to the company and not to the shareholder the claim belongs to the company to the exclusion of the shareholder, ${ }^{115}$ who is restricted to a derivative action, or, now, a claim under section 459 to pursue a remedy for the company. Likewise where the defendant breaches a duty to a shareholder but has never owed a duty to the company then it is easy to see that the claim belongs to the shareholder to the exclusion of the company, even if the only loss suffered by the shareholder is a diminution in the value of his or her shares in the company. ${ }^{116}$ However, difficulties arise where the defendant breaches separate duties to the company and to the shareholder. In Prudential Assurance Co. Ltd. v. Newman Industries Ltd. (No. 2), ${ }^{117}$ the defendant company directors had made a fraudulent misrepresentation in a circular issued to the members in order to win their consent to the company purchasing assets at an over value from a second company in which the directors had a personal interest. The claimant, which owned three per cent. of the shares, brought a derivative action against the directors, alleging that they had committed the tort of conspiracy against the company. In addition the claimant brought a personal action against them, alleging that they had also committed the tort of conspiracy against the members. The Court of Appeal refused the personal action on the basis that the claimant had suffered no loss:

[A shareholder] cannot recover a sum equal to the diminution in the market value of his shares, or equal to the likely diminution in dividend, because such a "loss" is merely a reflection of the loss suffered by the company. The shareholder does not suffer any personal loss. His only 'loss' is through the company, in the diminution in the value of the net assets of the company, in which he has (say) a 3 per cent. shareholding. The plaintiff's shares are merely a right of participation in the company on the terms of the articles of association. The shares

\footnotetext{
${ }^{114}$ See however Atlasview Ltd. v. Brightview Ltd. [2004] EWHC 1056; [2004] 2 B.C.L.C. 191, discussed below.

115 E.g., Stein v. Blake [1998] 1 All E.R. 724.

116 See George Fischer (Great Britain) Ltd. v. Multi Construction Ltd. [1995] 1 B.C.L.C. 260

${ }^{117}$ [1982] Ch. 204.
} 
themselves, his right of participation, are not directly affected by the wrongdoing. ${ }^{118}$

The distinction drawn by the Court of Appeal in Prudential was an artificial one. Shareholders do undoubtedly suffer a loss when the market value of their shares goes down, or when a company stops paying dividends, as the House of Lords in Johnson v. Gore Wood $\&$ Co. ${ }^{119}$ have now confirmed. Instead, the shareholder is debarred from claiming this personal loss for policy reasons. In order to avoid the spectre of double recovery, justice to the defendant requires that the claim in relation to a wrong which causes loss to both the company and to the shareholder be given to one victim at the expense of the other. Their Lordships chose to give the claim to the company in order to protect the interests of the company's creditors. $^{120}$ Their Lordships were concerned with two issues: collective action and collective recovery. Their Lordships applied these principles strictly, allowing that reflective loss can only be recovered where the company has never had a cause of action against the defendant. ${ }^{121}$ However, shareholders can recover if the defendant breaches a duty to them and they suffer loss which is "separate and distinct from that suffered by the company"122 as a result of the wrongdoer's action. A simple example of such separate and distinct loss was given by the Court of Appeal in Prudential: "if directors convene a meeting on the basis of a fraudulent circular, a shareholder will have a right of action to recover any loss which he has been personally caused in consequence of the fraudulent circular; this might include the expense of attending the meeting" 123 even if the company can also claim the loss it separately sustains as a result of the director's action.

The relevance of reflective loss principles in a section 459 petition has recently been considered by the High Court in Atlasview Ltd. v. Brightview Ltd. ${ }^{124}$ The petitioners brought a

\footnotetext{
118 Ibid., at pp. 222-223. This sits uneasily with the views of Lord Hoffmann in O'Neill v. Phillips [1999] 1 W.L.R. 1092.

${ }^{119}$ [2000] UKHL 65; [2002] 2 A.C. 1.

120 Ibid., at p. 62 per Lord Millett.

121 The extent of this principle is still uncertain. What if the company simply chooses not to pursue the action, or settles for a lesser amount? The House of Lords in Johnson v. Gore Wood were clear that a shareholder should not be able to recover reflective loss where a company has settled with the defendant: Lord Millett at p. 66 but cf. Lord Cooke at p. 47. However see C. Mitchell, "Shareholders' Claims for Reflective Loss" (2004) 120 L.Q.R. 457, 470. Should the company be regarded as having no claim if it is now insolvent? Does it matter how the company became insolvent? The Court of Appeal in Giles v. Rhind [2002] EWCA Civ 1428; [2003] Ch. 618 were inclined to be generous where the misbehaviour of the wrongdoer was regarded as having caused the company's insolvency, but the extent of this derogation from the reflective loss principle is still unclear.

122 Ibid., at p. 35 per Lord Bingham.

123 [1982] Ch. 204, 222.

124 [2004] EWHC 1056; [2004] 2 B.C.L.C. 191.
} 
section 459 action on the basis that the defendants had breached an investment agreement between themselves and the petitioners in committing the company to an ill-judged loan agreement. The petitioners sought a variety of remedies including damages. The defendants put forward a number of arguments, including the fact that the claim for damages was based soley on the alleged breaches of fiduciary duty by a number of the directors of the company, that no breach of duty to any shareholders had been alleged, that the company was therefore the proper claimant and that any diminution in the value of the petitioners' shares was merely reflective loss. The judge did not regard these arguments as sufficient to justify the requested strike out. He put forward three arguments to support his view. First, cases in the past have allowed shareholders to obtain a personal remedy where a breach of duty has occurred. He cited inter alia, Re A Co. ${ }^{125}$ and Re Saul D. Harrison \& Sons plc ${ }^{126}$ as examples of cases in which it was accepted that shareholders could include allegations of wrongdoing to the company to support a section 459 petition and in which the reflective loss point was not even argued. As a result, he suggested the reflective loss issue has no application in section 459 petitions. Second the legislation was specifically changed in order to allow unfair prejudice "to the interests of the members generally" to be included $^{127}$ and to allow the reflective loss argument to succeed would rob this amendment of its effect. Third, if the reflective loss argument succeeded then the only option would be for the court to require the shareholder to follow the derivative action route which is cumbersome and awkward. However the latter two points do not require that the shareholders should receive personal relief. If section 459 is used to provide a remedy to the company alone, as occurred in Clark v. Cutland, then these two arguments drop away. The first point requires more thought, but the mere fact that a reflective loss argument has not been raised in the past is not a good reason for that argument not to succeed in the future. It should be borne in mind that all of the cases cited by the judge appeared well before the decision in Johnson v. Gore Wood in which the profile of reflective loss was raised beyond all recognition.

Starting from first principles, it is not surprising that where a shareholder brings a petition under section 459 complaining, say, that they have been improperly removed from their directorship, the loss suffered by the individual will not be regarded as reflective loss, providing there is no wrong done to the company at the same

125 [1986] B.C.L.C. 68.

126 [1995] 1 B.C.L.C. 14

127 See note 14 and associated text. 
time. This will be the case where the only complaint arises from informal arrangements which have arisen between the shareholders in a quasi-partnership company. If no duty to the company is breached then the shareholder can claim relief. However, what if the claim is brought by the shareholder in circumstances in which a duty to the company has also been breached? This is a common scenario in section 459 petitions. Where shareholders base their claim on a breach of the articles, it is clear that such a breach constitutes both a wrong to the shareholders and a wrong done to the company. ${ }^{128}$ In addition, where the section 459 petition is founded on a breach of duty to the company, this constitutes both a wrong done to the company and an indirect wrong to the shareholder when the controllers misuse their control of the company to prevent an action being brought. ${ }^{129}$

Of course, it could be argued that even in these circumstances, the claim under section 459 is a personal one, for personal relief, albeit based on a corporate wrong. In support of this argument are the cases which make it clear that, in contrast to a derivative action, company assets should in general not be used to fund a section 459 claim. ${ }^{130}$ One difficulty with this view is the fact that the reflective loss cases have been phrased not in terms of the nature of the relief sought, but in terms of the nature of the wrong suffered. Whilst reflective loss as a concept can be criticised, ${ }^{131}$ once it is accepted it requires all claims regarding wrongs done to the company to be mediated through the company. The no reflective loss principle requires that personal relief should be refused on the basis that the proper claimant for the loss is the company itself. This is so even where, as in Atlasview, separate claims arise in the shareholders' hands. In that case the claimants simultaneously brought both the section 459 petition and a breach of contract claim against the wrongdoers for breach of the investment agreement to which the petitioners and the wrongdoers were both party. ${ }^{132}$ However, this is no different from many other cases in

${ }_{128}$ R. Smith, "Minority Shareholders and Corporate Irregularities" (1978) 41 M.L.R. 147.

129 Report of the Company Law Committee, Cmnd. 1749 (1962), para. 206.

130 The general principle is that company's money should not be expended in disputes between the shareholders: Pickering v. Stephenson (1872) LR 14 Eq. 322; Re Crossmore Electrical and Civil Engineering Ltd. [1989] B.C.L.C. 137, 138 per Hoffmann J. However, it is acknowledged that it may be proper for the company's money to be used where it can be shown to be necessary or expedient in the interests of the company as a whole, although there is a "rebuttable distaste" for such a proposition: Re A Company No. 1126 of 1992 [1994] 2 B.C.L.C. 146, 155-6 per Lindsay J.; Arrow Trading \& Investments Est. 1920 v. Edwardian Group Ltd. (No. 1) [2004] B.C.C. 977, at [11] per Ferris J. Of course, as Clark v. Cutland now makes clear, costs may be recovered from the company where section 459 is used to seek a substantive remedy for the company.

131 C. Mitchell, "Shareholders' Claims for Reflective Loss" (2004) 120 L.Q.R. 457.

132 Another example is Re A Company [1986] B.C.L.C. 68 which involved competing takeover bids being made for a company. The directors breached their duty to the company in 
which the shareholders' loss has been held to be merely reflective of the company's loss. ${ }^{133}$

The decision in Clark v. Cutland has made it harder to sustain the argument that reflective loss has no place in section 459 claims. It is difficult to see why reflective loss should not be relevant where section 459 is being used as an alternative to a derivative action. If Mr. Clark had also sought an award of damages for the diminution in the value of his shares, surely this would have been blocked by the no reflective loss principle. However, just because the company's claim is not pursued or there is some defence to the company's claim, the shareholder will not be allowed to pursue his claim: "[t]he company's claim, if it exists, will always trump that of the shareholder." 134 The court has no discretion in such circumstances. ${ }^{135}$ The claim cannot be entertained. The fact that no substantive remedy was sought for the company in Atlasview does not mean that the reflective loss principle should not apply. This is particularly clear on the facts of Atlasview in which the shareholders were claiming equitable compensation for themselves for the wrongs done to the company, although such claims are admittedly rare and the jurisdiction to award such compensation is not well-developed.

What about the situations in which the shareholder is seeking some other form of recovery, such as where the loss is suffered qua director? These claims are more common in section 459 petitions than the compensation claim seen in Atlasview. The reflective loss cases have employed a narrow definition of separate and distinct loss to date, so that losses suffered in another capacity have often still been regarded as reflective loss. Lord Millett has stated:

Reflective loss extends beyond the diminution of the value of the shares; it extends to the loss of the dividends ... and all other payments which the shareholder might have obtained from the company if it had not been deprived of its funds. All transactions or putative transactions between the company and its shareholders must be disregarded. Payment to the one diminishes the assets of the other. In economic terms, the shareholder has two pockets, and cannot hold the defendant liable for his inability to transfer money from one pocket to the other. In principle, the company and the shareholder cannot together recover more than the shareholder would have

deciding to support one offer over the other, but also breached a duty to the shareholders since they had sought to advise the shareholders on the merits of the competing bids but without giving them sufficient information to allow the shareholders to make an informed choice.

133 E.g., Prudential Assurance Co. Ltd. v. Newman Industries Ltd. (No. 2) [1982] Ch. 204

134 Day v. Cook [2001] EWCA Civ 592; [2002] 1 B.C.L.C. 1, para. [38] per Arden L.J.

135 Johnson v. Gore Wood \& Co. [2000] UKHL 65; [2002] 2 A.C.1 cf. Christensen v. Scott [1996] 1 N.Z.L.R. 273 
recovered if he had carried on business in his own name instead of through the medium of a company. On the other hand, he is entitled (subject to the rules on remoteness of damage) to recover in respect of a loss which he has sustained by reason of his inability to have recourse to the company's funds and which the company would not have sustained itself. ${ }^{136}$

In addition to the more obvious forms of reflective loss, such as loss of share value and loss of dividends, funds which a shareholder would have received qua employee have also been regarded as reflective losses, even where the shareholder has a legal claim to be paid those qua employee losses. ${ }^{137}$ Similarly, where the shareholder's loss is suffered qua director the starting point is that these losses are not recoverable. Therefore in general loss of salary and of pension contributions are regarded as reflective losses ${ }^{138}$ although the House of Lords in Johnson v. Gore Wood stated that the claimant could recover the loss of enhancement of the value of his pension. ${ }^{139}$ The recent case of Gardner v. Parker ${ }^{140}$ involved a shareholder suing qua creditor to recover losses suffered as a result of breaches to the company by the defendant director. This was held to be reflective loss, as it was loss which would be made good if the company had enforced its rights in full against the defendant. The capacity in which the claimant suffered the loss was irrelevant. In general then, the no reflective loss principle ought to debar a shareholder from recovering for monetary losses of this kind where the wrongdoer has breached duties to the company as well as to the shareholder, even where the shareholder petitions under section 459.

Of course the most commonly requested remedy in section 459 cases is not a monetary order of this kind, or a compensation claim such as that in Atlasview, but a buy out order. It could be argued that this falls outside the remit of reflective loss altogether, being a personal remedy for the shareholder to exit the company, and therefore that it presents no danger in reflective loss terms. The counter argument is that the valuation of the shares prior to exit contains an element of reflective loss because the wrong to the company is compensated before the shareholder is paid. The judge in Atlasview, when discussing the potential effect of reflective loss

\footnotetext{
136 Johnson v. Gore Wood \& Co. [2000] UKHL 65; [2002] 2 A.C.1, 66-67.

${ }^{137}$ Ibid., at p. 67 per Lord Millett.

138 Ibid., at p. 36 per Lord Bingham.

139 When the claims for separate and distinct loss came for trial in Johnson v. Gore Wood \& Co. (No. 2) [2003] EWCA Civ 1728 Hart J. thought it was "not obvious" what their Lordships had had in mind in making this distinction, given that the benefit derived from any pension policy is the product of the contributions paid. In the end he allowed the claimant to recover the loss of the tax benefit from investing in a pension policy.

140 [2004] EWCA Civ 781; [2004] 2 B.C.L.C. 554.
} 
on the buy out remedy, did not suggest that reflective loss can have no relevance in this regard. Instead he suggested that it would have no relevance as long as double recovery is avoided. The judge argued that there was no danger of double recovery provided the company is compensated first and then the shareholder's shares are bought. ${ }^{141}$ The only danger of double recovery, he argued, arises if the shareholder stays in the company after compensation occurs. However, this misses the general point that reflective loss is intended to ensure that actions involving wrongs to the company are mediated via the company for public policy reasons, in order to protect the other shareholders and the creditors of the company. Reflective loss is about more than avoiding double recovery. As stated, even if the company's claim is not pursued or there is some defence to the company's claim, the shareholder will not be allowed to pursue his claim. The exclusion of reflective loss from buy out requests on this basis does not seem well founded. It seems likely that this is an issue to which the courts will have to return, in order to determine whether the buy out remedy does indeed infringe reflective loss principles. Ultimately this is likely to be a policy issue for the courts. It can be argued that a buy out order infringes reflective loss principles, because of the valuation point, but to allow this argument would seem to undermine much of the statutory protection which section 459 seeks to bestow on minority shareholders. The resolution of this issue is likely to determine whether reflective loss impacts heavily on section 459 claims in practice. It is hoped that the courts would err on the side of shareholder protection.

Reflective loss does have a role to play in section 459 cases. Clark v. Cutland does not exacerbate the problem regarding reflective loss, since that decision merely allows that the minority shareholder can obtain a corporate remedy via section 459. This does not offend reflective loss principles if that is the only remedy sought. Indeed that decision is arguably more in tune with reflective loss principles than previous cases in which the company was denied but the shareholder was allowed to claim personal relief on the basis of a wrong done to the company. ${ }^{142}$ The fact that Clark v. Cutland allows section 459 to be used as a genuine alternative to a derivative action, does, however, make it particularly difficult to argue that reflective loss principles can be central to one, but irrelevant to the other. Shareholders in a case like Atlasview should be able to use the section 459 petition to seek a remedy for the

${ }^{141}$ [2004] EWHC 1056; [2004] 2 B.C.L.C. 191, para. [63] per Jonathan Crow, sitting as a deputy judge of the high court.

142 E.g., Re Charnley Davies Ltd. (No. 2) [1990] B.C.L.C. 760. 
company but not per se for themselves unless they can demonstrate that their loss is separate and distinct from the company's loss. However, as with the development of reflective loss in other areas, the difficulty will be to determine the boundaries of this principle in the context of section 459. Determining shareholders' ability to obtain personal relief in section 459 cases, where a wrong has also been done to the company, particularly in relation to the buy out remedy, may not be straightforward.

\section{H. Public Companies}

The decision in Clark v. Cutland suggests that, depending on the exact nature of their complaint, shareholders in public companies may be better served by a section 459 petition than by a derivative action. There is no restriction on minority shareholders in public companies being able to bring derivative actions. Such actions are possible, though rare, in part because many shareholders in public companies will prefer to sell their shares on the market rather than launch difficult and costly litigation. ${ }^{143}$ Institutional shareholders, though technically minority shareholders, may well have sufficient authority and power within the company to achieve their goal without recourse to the formalities of the general meeting, let alone having to resort to litigation. It has also been suggested that there is an implicit acceptance by the judiciary that "it is somehow undesirable that large public companies should be exposed to civil litigation by minority shareholders". ${ }^{144}$

As regards section 459, there is nothing within the terms of the legislation to prevent the shareholders of listed companies from bringing a petition. However, it has previously been accepted that section 459 is of limited benefit to such shareholders. Jonathan Parker J. has said that "[i]f the market in a company's shares is to have any credibility members of the public dealing in that market must it seems to me be entitled to proceed on the footing that the constitution of the company is as it appears in the company's public documents, unaffected by any extraneous equitable considerations and constraints". ${ }^{145} \mathrm{He}$ also specifically rejected the idea that minority shareholders in such companies could have expectations based on the Listing Rules, the City Code or the Cadbury Code. ${ }^{146}$ On this analysis, such shareholders are being limited to petitions based, for example, on rights arising under

\footnotetext{
143 On a practical level, the test of wrongdoer control (see Prudential Assurance Co. Ltd. v. Newman Industries Ltd. (No. 2) [1982] Ch. 204) may be harder to satisfy in a public company where shareholdings tend to be more dispersed.

144 Boyle, Minority Shareholders' Remedies, p. 12.

145 Re Astec (BSR) plc [1998] 2 B.C.L.C. 556, 589

146 Ibid., at p. 590 .
} 
breaches of the articles, or from breaches of directors' duties. Certainly if the shareholder is seeking a personal remedy, given that the most common is a buy out of their shares, the readily available market place for the shareholders' shares will generally provide a more attractive option. However, in the wake of Clark v. Cutland there is no reason why a minority shareholder in a public company should not launch a section 459 petition on the company's behalf where a breach of a duty owed to the company has occurred.

\section{Remedies}

The remedies available to the court under section 461 of the Companies Act 1985 are much wider than those available to the court in a derivative action. The current ambit of the fraud on the minority exception to Foss v. Harbottle seems to allow a derivative action to be brought where the directors use their powers fraudulently or negligently in a manner which benefits themselves at the expense of the company. ${ }^{147}$ It is unsurprising therefore that the remedies awarded by the courts in derivative actions revolve around the recovery of property belonging to the company or a damages claim. In a derivative action the court may make an order against the wrongdoers themselves and/or against a third party where it is necessary to do so, for example where general equitable principles permit remedies against such parties. The constructive trust and tracing rules are examples of such principles. This would not alter under the proposals put forward by the Law Commission. ${ }^{148}$

Under section 461 there is a general power for the court to make such order as it thinks fit for giving relief in respect of the matters complained of, ${ }^{149}$ which is without prejudice to the more specific powers in section 461(2). The most common remedy of course is the power to order that the complainant's shares be bought by the company but there are also powers to regulate the company's affairs in the future, ${ }^{150}$ to alter the articles and memorandum of the company, ${ }^{151}$ and to authorise civil litigation on behalf of the company by a minority shareholder. ${ }^{152}$ It was doubted for some time whether section 461 could be used to provide a direct substantive remedy to the company rather than this latter indirect procedural remedy. ${ }^{153}$ This has now been clarified by the Court of Appeal in Clark v. Cutland. There is no doubt that when

147 Daniels v. Daniels [1978] Ch. 406, 414 per Templeman J.

148 See Law Com. No. 246, Shareholders' Remedies (1997), Appendix A, draft Bill section 458(3).

149 Companies Act 1985, section 461 (1).

150 Ibid., at section $461(2)(\mathrm{g})$.

151 Ibid., at section 461 (3).

152 Ibid., at section $461(2)(\mathrm{c})$.

153 E.g., Re Charnley Davies Ltd. (No. 2) [1990] B.C.L.C. 760; Re Saul D. Harrison \& Sons plc [1995] 1 B.C.L.C. 14 cf. Lowe v. Fahy [1996] 1 B.C.L.C. 262. 
used as an alternative to the derivative action section 459 offers a range of remedies to the court which is wider than the remedies available under the derivative action itself. This is the case when the court needs to award a remedy vis-ä-vis the wrongdoer, but the courts have demonstrated a willingness to make orders against third parties where this is necessary. ${ }^{154}$

\section{CONCLUSION}

The decision of the Court of Appeal in Clark v. Cutland has expanded the potential use of section 459 , to enable it to be used as a real alternative to the derivative action for minority shareholders who wish to pursue a substantive remedy for their company. This article has analysed the differences between a section 459 petition and a derivative action for such shareholders. This analysis demonstrates that section 459 provides the more flexible and useful route for shareholders seeking to pursue a corporate claim. In particular, section 459 provides a greater breadth of protection and is available to corporate groups in a way in which derivative actions are not, and the range of remedies available under section 461 is wider. Indeed, one of the few areas in which the derivative action is more attractive to minority shareholders is in relation to costs. Although Clark v. Cutland accepts that an indemnity costs order may be awarded to a shareholder who seeks a remedy for the company, this order will only be made after the event, not prior to the hearing as in a derivative action. However, it is possible that conditional fee agreements will be allowed when using section 459 to pursue a remedy for the company, whereas they do not seem to be available in derivative actions. There is much to suggest that the derivative action will be effectively superceded by section 459 petitions in the future.

The proposals for the reform of both derivative actions and section 459 put forward by the Law Commission, broadly, endorsed by the Company Law Review, ${ }^{155}$ and now included in the Company Law Reform Bill ${ }^{156}$ will make little difference to the issues raised in this article. ${ }^{157}$ Reform plans in this area need to be rethought. Instead of maintaining the current divide between these two forms of shareholder litigation, the reform proposals should bow to the inevitable and roll the derivative action into the section

\footnotetext{
154 Re Little Olympian Each-Ways Ltd. (No. 3) [1995] 1 B.C.L.C. 636.

155 See Modern Company Law for a Competitive Economy, Developing the Framework, URN 00/ 656 (March 2000), Completing the Structure, URN 00/1335 (November 2000) and the Final Report, URN 01/942 and 943 (June 2001).

${ }^{156}$ See Company Law Reform Bill, Part O (available at www.dti.gov.uk/cld/pdfs/ derivativeclaimsclauses.pdf).

157 Law Commission, Shareholders' Remedies (Law Com. No. 246, 1997).
} 
459 petition since that is what Clark v. Cutland now allows in practice. However, two particular areas of concern have been raised by this article and will need to be addressed. First, when section 459 is used as a collective procedure, to obtain a remedy for the company, some protection needs to be embedded into section 459 to ensure that the procedure is not misused by malicious or misguided shareholders. This could best be done by requiring the collective position of the shareholders, including issues such as ratification and the views of an independent organ, to be taken into account at the pre-trial review when assessing whether the action should proceed. Second, the issue of reflective loss requires more thought in the context of section 459. It has not been applied in section 459 petitions to date but there does not seem to be any good reason why the principles of reflective loss should not be applicable in relation to some section 459 petitions. On that basis shareholders in a case like Atlasview could use the section 459 petition to seek a remedy for the company but not per se for themselves unless they could demonstrate that their loss is separate and distinct from the company's loss. The Clark v. Cutland decision does not exacerbate the problem regarding reflective loss, since that decision merely allows that the minority shareholder can obtain a corporate remedy via section 459. This does not offend reflective loss principles if that is the only remedy sought. However, that decision does make it particularly difficult to argue that while reflective loss principles are central to an application of derivative action principles they have no part to play in section 459 petitions. 